\title{
IMPLEMENTASI PENDIDIKAN AGAMA ISLAM (PAI) BERWAWASAN BUDAYA NIRKEKERASAN DI SEKOLAH
}

\author{
Oleh: \\ Siti Mutholingah
}

Email: siti.mutholiah@yahoo.co.id

\begin{abstract}
ABSTRAK
Konflik kekerasan yang mengatasnamakan agama sudah menjadi permasalahan serius. Hal ini disebabkan karena lemahnya pemahaman terhadap ajaran Islam itu sendiri, atau bisa dikarenakan pemahaman ayat-ayat al-Qur'an mengenai konsep jihad secara tektualis. PAI berbasis budaya nirkekerasan sebagai upaya untuk menumbuh kembangkan potensi peserta didik sesuai dengan ajaran Islam yang berbudaya nirkekerasan, maka dalam hal ini pendidik harus mampu menciptakan budaya nirkekerasan baik di rumah, di sekolah, maupun masyarakat sehingga outputnya adalah peserta didik yang mampu menjadi Abdullah (saleh individu) maupun khalifatullah (saleh sosial). Adapun dalam tataran implementasi PAI berbudaya nirkekerasan di sekolah dapat diimplementasikan dalam bentuk integrasi dengan kegiatan intrakurikuler, ekstrakurikuler PAI, pembentukan budaya sekolah berdasar pada nilai-nilai nirkekerasan, adanya kebijakan kepala sekolah dan integrasi dengan setiap mata pelajaran yang ada di sekolah.
\end{abstract}

\section{Kata kunci: Implementasi PAI, budaya Nirkekerasan, Sekolah}

\section{A. Pendahuluan}

Ada dilema besar yang dihadapi umat Islam saat ini yakni di satu sisi, Islam mengajarkan mereka untuk melawan ketidakadilan. sedangkan, di sisi lain, Islam juga mengatur tata tindakan mana yang diperbolehkan dalam melakukan perlawanan. ${ }^{1}$ Dilema inilah yang kiranya menjadi latara belakang munculnya berbagai kekerasan yang kental bernuansakan keagamaan. Ada yang melakukan kekerasan dengan berdalih menegakkan (berjihad) Agama Islam, ada pula pula yang berdalih bahwa kaum minoritas hendaknya disingkirkan atau bahkan dimusnahkan karena dianggap mengganggu stabilitas kaum mayoritas.

\footnotetext{
1 Pusat Studi Agama dan Demokrasi Yayasan Paramadina (PUSAD), http://www.paramadina-pusad.or.id/pustaka/barangsiapa-memelihara-kehidupanesai-esai-tentang-nirkekerasan-dan-kewajiban-islam, diakses 1 November 2017
} 
Jika kita melihat beberapa tahun ke belakang, khususnya di Indonesia berapa kasus yang berlatarbelakang sosial keagamaan telah terjadi. Menurut SNPK (Sistem Nasional Pemantau Kekerasan), pada tahun 2012, 53 orang tewas dan 629 terluka di wilayah Jabodetabek akibat vigintalisme, yakni main hakim sendiri dengan berdalih landasan agama. ${ }^{2}$ Belum lagi tindakantindakan anarkis yang dilakukan oleh GAPAS (Gerakan Anti Pemurtadan dan Aliran Sesat) dan FUI (Forum Ukhuwah Islamiya) yang melakukan berbagai aksi kekerasan, misalnya di tahun 2008 menutup sebuah stasiun televise Kristen, pada awal tahun 2010 mereka menyerang kampung Ahmadiyah di Manis Lor dan pada tahun yang sama sekaligus melakukan serangkaian serangan terhadap karaoke serta supermarket yang menjual minuman keras atau bir. ${ }^{3}$ Hal ini merupakan indikator betapa ironisnya kondisi bangsa Indonesia ini jika ditelisik dari masalah kekerasan.

Belum lagi jika kita melihat dalam konteks yang lebih luas sedikit dan lebih aktual, yakni di awal dan pertengahan tahun 2017 ini media massa ramai memberitakan terkait kasus etnik Rohingnya di Myanmar yang kembali mengalami kekerasan sejak Jumat pekan lalu. Polisi dan militer Myanmar membakar rumah perkampungan mereka. Tak hanya itu, mereka yang berusaha melarikan diri menggunakan kapal tongkang ditembaki aparat. Setidaknya 20 mayat perempuan dan anak-anak terbawa arus dan muncul di sungai di Bangladesh, negara tetangga yang menjadi tujuan pelarian mereka. ${ }^{4}$

Dua pandangan kerap muncul ketika terjadi kekerasan yang kental bernuansa keagamaan, seperti yang saat ini terjadi terhadap Muslim Rohingya di Rakhine, Myanmar tersebut. Pertama, pandangan yang menilai agama sebagai biang keladi atau penyebab utama kekerasan. Kedua, pandangan yang menilai agama sekadar alat yang dipakai oleh pihak yang sedang berkonflik. ${ }^{5}$

Belum lagi kalau kita melihat berbagai macam kekerasan di Timur Tengah yang terjadi antar kelompok muslim, antara kelompok sunni dengan syi'i, antara kelompok ISIS dengan pemerintah Suriah, dan lain sebagainya. Sepertinya kekerasan sudah menjadi suatu budaya yang mengakar di manapun, baik di Indonesia atau di luar negeri sekalipun.

2 Sidney Jones, Sisi Gelap Reformasi Indonesia: Munculnya Kelompok Masyarakat Madani Intoleran, (disampaikan sebagai NMML [Nurcholish Madjid Memorial Lecture ke VII], Jakarta 19 Desember 2013), (Jakarta: PUSAD), hlm. 1

${ }^{3}$ International Crisis Group,"Indonesia: From Vigintalism to Terrorism in Cirebon," Asia Briefing No. 132, 12 January 2012

${ }^{4}$ CNN Indonesia, Puluhan Jenazah Warga Rohingnya Ditemukan di Bangladesh, Kamis, $31 / 08 / 2017$

${ }^{5}$ Husni Mubarak, Tragedi Rohingnya dan Diskursus Kekerasan Agama, Jurnal Kelas CRCS, 4 September 2017 (Yogyakarta: Pusat Studi Agama dan Lintas Budaya Sekolah Pascasarjana UGM), http://crcs.ugm.ac.id/id/berita-utama/11384/tragedi-rohingyadan-diskursus-kekerasan-agama.html, diakses 1 November 2017 
Dari beberapa kasus kekerasan bernuansakan agama tersebut, bisa menjadi indikator bahwasannya betapa belum mampunyai kesadaran beragama yang pluralis manusia ini, khususnya umat Islam dalam memahami, menghayati dan mengamalkan ajaran Islam yang rahmatan lil'alamin. Padahal sesungguhnya ajaran Islam yang dibawa oleh Rasulullah dengan penuh pesan perdamaian. Islam yang diajarkan Rasulullah tidak pernah memihak pada kaum mayoritas maupun kaum minoritas, dan Islam yang ajarkan oleh Rasulullah adalah Islam pluralis-multikulturalis.

Sudah saatnya peran agama dalam menopang perdamaian ditekankan kembali, diingat kembali, dan ditampilkan kembali sebagai sesuatu yang menarik, yang mungkin, doable, dan penting. Karena sesungguhnya sumber normatif nirkekerasan dan dukungan kepada perdamaian bukan saja sudah ada dalam tradisi agama-agama, atau telah terpateri dalam sejarah para nabi atau sahabat mereka, tetapi juga sudah dan masih dipraktikkan oleh para aktornya di tempat dan konteks tertentu. Dan inilah Pendidikan Agama Islam sebagai usaha mengajarkan Agama Islam beserta aktor-aktor di dalamnya mempunyai peranan penting untuk mewujudkan budaya nir-kekerasan sebagai anti-tesis sekaligus solusi dari budaya kekerasan tersebut.

\section{B. Pembahasan}

\section{Hakikat \& Landasan Pendidikan Agama Islam}

Menurut Naquib al-Attas lebih memilih ta'dib (menanamkan adab) sebagai arti dari pendidikan Islam dibandingkan dengan tarbiyah dan ta'lim. Sebab ta'dib menurut beliau sudah mencakup unsurunsur ilmu ('ilmu), instruksi (ta'lim), dan pembinaan yang baik (tarbiyah). ${ }^{6}$ Melalui konsep ta'dib ini dapat mencetak manusia yang beradab ${ }^{7}$, yang dengannya dapat terhindar diri dari sifat-sifat kezhaliman (zhulm), kebodohan (jahl), dan kegilaan (junun). Jadi jika seorang itu telah beradab, secara otomatis telah memiliki ilmu pengetahuan serta punya daya bina yang baik.

Konsep $t a^{\prime} d i b$ ini didasarkan pada hadits Nabi berikut ini:

$$
\text { أدبنى ربى فأحسن تأدبى }
$$

6 Wan Mohd Nor Wan Daud, The Educational Philosophy and Practice of Syed Muhammad Naquib Al-Attas: an Exposition of the Original Concept of Islamization, (Kuala Lumpur: ISTAC1, 1998), hlm. 170

7 Menurut al-Attas manusia beradab adalah orang yang baik itu adalah yang menyadari sepenuhnya akan tanggung jawab dirinya kepada Tuhan yang haq, yang memahami dan menunaikan kewajiban terhadap dirinya sendiri dan orang lain yang terdapat dalam masyarakatnya, yang selalu berupaya meningkatkan setiap aspek dalam dirinya menuju kearah kesempurnaan sebagai manusia yang beradab. (Risalah Untuk Kaum Muslimin, hal. 152) 
"Tuhanku telah mendidikku, dan dengan demikian menjadikan pendidikanku yang terbaik".

Dalam pandangan al-Attas, dengan menggunakan term "ta'dib" di atas, dapat dipahami bahwa pendidikan Islam adalah proses internalisasi dan penanaman $a d a b$ pada diri manusia. Sehingga muatan substansial yang terjadi dalam kegiatan pendidikan Islam adalah interaksi yang menanamkan adab. Seperti yang diungkapkan al-Attas, bahwa pengajaran dan proses mempelajari ketrampilan betapa pun ilmiahnya tidak dapat diartikan sebagai pendidikan bilamana di dalamnya tidak ditanamkan 'sesuatu'. 8

Jadi, Pendidikan Agama Islam menurut Naquib al-Attas adalah upaya untuk menanamkan dan menumbuhkembangn adab atau etika kepada pesera didik, sehingga menjadi manusia mampu hidup dengan baik secara materail maupun spiritual.

Sedangkan menurut Jalaluddin, Pendidikan Agama Islam diartikan sebagai upaya sadar yang dilakukan oleh mereka yang memiliki tanggung jawab terhadap pembinaan, bimbingan, pengembangan serta pengarahan potensi yang dimiliki anak agar mereka dapat berfungsi dan berperan sebagaimana hakikat kejadiannya. ${ }^{9}$ Jadi PAI merupakan pembinanaan, pembibingan dan pengembangan potensi baik peserta didik yang dilakukan oleh pendidik, sehingga peserta didik mempunyai bekal potensi tersebut untuk menjalankan kehidupannya sebagai hamba Allah sekaligus khalifah Allah.

Sementara menurut Zakiah Daradjat, Pendidikan Agama Islam adalah pendidikan melalui ajaran-ajaran agama Islam, yaitu berupa bimbingan dan asuhan terhadap anak didik agar nantinya setelah selesai dari pendidikan itu ia dapat memahami, menghayati, dan mengamalkan ajaran-ajaran agama Islam yang telah diyakininya secara menyeluruh, serta menjadi ajaran agama Islam sebagai suatu pandangan hidupnya demi keselamatan dan kesejahteraan hidup di dunia maupun kelak di akhirat. ${ }^{10}$

Menurut Muhtar, pembelajaran PAI adalah suatu proses yang bertujuan untuk membantu peserta didik dalam belajar agama Islam. Pembelajaran ini akan lebih membantu dalam memaksimalkan kecerdasan peserta didik yang dimiliki, menikmati kehidupan, serta kemampuan untuk berinteraksi secara fisik dan sosial terhadap lingkungan. ${ }^{11}$

8 Abdul Kholiq, dkk., Pemikiran Pendidikan Islam, Kajian Tokoh Klasik dan Kontemporer, (Yogyakarta: Pustaka Pelajar, 1999), hlm. 275

9 Jalaluddin, Psikologi Agama. (Jakarta: PT. RajaGrafindo Persada, 2004), hlm. 19

${ }_{10}$ Zuhdiyah, Pendidikan Agama Islam (Palembang : Universitas PGRI, 2009) Hlm 6-7

${ }^{11}$ Mukhtar, Desain Pembelajaran PAI, (Jakarta: Misaka Galiza, 2003), cet. III, hlm. 14 
Dari berbagai pendapat para tokoh di atas, dapat disimpulkan bahwa Pendidikan Agama Islam adalah proses ataupun usaha sadar untuk menumbuh kembangkan segala potensi manusia dengan memberi sifat keIslaman (berlandaskan al Qur'an dan hadits), sehingga terbentuk kepribadian muslim yang bertaqwa yakni mentaaati atau melaksanakan segala perintah Allah dan menjauhi segala yang dilarangNya, beramar ma'ruf nahi mungkar, serta memiliki nilai-nilai agama Islam, memilih, memutuskan, serta berbuat berdasarkan nilai-nilai Islam dan bertanggung jawab sesuai dengan nilai-nilai Islam.

Dasar atau landasan dalam PAI identik dengan dasar tujuan Islam itu sendiri. Keduanya berasal dari sumber yang sama yaitu al Qur'an dan Hadits. Dengan merujuk kedua sumber ini, dengan bantuan metode qiyas, ijma', ijtihad, dan tafsir. ${ }^{12}$ Kemudian menurut Daud Ali, selain al-Qur'an dan hadits sebagai sumber utama ajaran Islam, ada sumber tambahan atau sumber pengembang yaitu ra'yu atau akal pikiran. Tetapi ra'yu di sini haruslah akal pikiran yang memenuhi syarat untuk bisa mengmbangkan alQur'an dan hadits sebagai sumber utama ajaran Islam, ${ }^{13}$ sehingga hasil dari ra'yu itu tidak bertentangan dengan al-Qur'an dan hadits melainkan senada dan seirama dengan al-Qur'an dan hadits.

\section{Tujuan Pendidikan Agama Islam Nir-kekerasan}

Menurut Naquib al-Attas, tujuan dari Pendidikan Agama Islam adalah tujuan pendidikan Islam adalah menanamkan kebajikan dalam "diri manusia" sebagai manusia dan sebagai diri individu. Tujuan akhir pendidikan Islam adalah menghasilkan manusia yang baik, yakni kehidupan materiil dan spirituilnya. Di samping itu, meskipun tujuan pendidikan Islam yang menitik beratkan pada pembentukan aspek pribadi individu, namun pembentukan masyarakat yang idel juga menjadi tujuan dari pensisikan Islam. ${ }^{14}$ Sebagaimana diungkapkan beliau berikut ini:

The purpose of seeking knowledge in Islam is to inculcate goodness in man and individual self. The end of uducation in Islam is to produce a good man, and not---as in the case of westren civilization--- to produce a good man, and citizen. By 'good' in the concept of good man is meant

\footnotetext{
12 Jalaluddin, Teologi Pendidikan, (Jakarta: PT Raja Grafindo Persada, 2003), hlm. 82 13 Mohammad Daud Ali, Pendidikan Agama Islam, (Jakarta: Raja Grafindo Persada), hlm. 90

14 Saiful Muzani, Pandangan Dunia dan Gagasan Islamisasi Ilmu Syed Muhammad Naquib Al-Attas, dalam Jurnal Hikmah, No. 3 Juli-Oktober 1991
} 
precisely the man of adab in the sence here explained as encompassing the spiritual and material life of man. ${ }^{15}$

Jadi pendidikan Agama Islam diharapkan mampu mencetak manusia yang baik etikanya secara individu (fisik dan spiritual), dan juga baik etikanya secara social sehingga mampu membentuk masyarakat yang beradab.

Menurut Hasan Langgulung (dalam Abuddin Nata), tujuan pendidikan agama harus mampu mengakomodasikan tiga fungsi utama dari agama, yaitu fungsi spiritual yang berkaitan dengan akidah dan iman, fungsi psikologis yang berkaitan dengan tingkah laku individual termasuk nilainilai akhlak yang mengangkat derajat manusia ke derajat yang lebih sempurna, dan fungsi sosial yang berkaitan dengan aturan-aturan yang menghubungkan manusia dengan manusia lain atau masyarakat. ${ }^{16}$

Hal tersebut menegaskan bahwa tujuan pendidikan Islam berpijak pada nilai-nilai Islam itu sendiri. Sementara itu, Ali Yafie menyebutkan bahwa pendidikan agama Islam mempunyai kontribusi yang penting, karena pendidikan agama Islam dapat meningkatkan wawasan keIslaman masyarakat, sehingga dapat memahami dan menghayati ajaran agama yang akan mengantarkan kepada pengamalan yang sempurna. ${ }^{17}$

Menurut al Jamali (dalam Baharuddin), aktualisasi seluruh potensi manusia sehingga manusia bisa menjadi khalifatullah dan Abdullah adalah menjadi tujuan akhir dari pendidikan Islam. 18 Dalam Konferensi Pendidikan Islam International sebagaimana dikutip oleh Haidar P. Daulay disebutkan sebagai berikut:

"The aim of Muslim education is the creation of the good and rightneous man who worship Allah in the true sense of the term, build up the structure of his earthy life according to the syari'ah (law) and employs it to subserve his faith). ${ }^{19}$

Dari beberapa pengertian di atas dapat disimpulkan bahwa tujuan utama pendidikan Islam dalam konteks nir-kekerasan adalah membentuk manusia yang baik secara fisik, mental, spiritual, maupun sosial, sehingga

${ }^{15}$ Mohammed Naquib al-Attas, The Concept of Education in Islam; A Framework for an Islamic Philosophy of Education, (Kuala Lumpur: ISTAC,1999,) hlm. 22

${ }^{16}$ Abuddin Nata, Filsafat Pendidikan Islam, Jakarta: Logos Wacana Ilmu, 1997, hlm. 46

${ }^{17}$ Ali Yafie, Teologi Sosial, Yogyakarta: LKPSM, 1997, hlm. 95

18 Baharuddin, Aktualisasi Psikologi Islami, Yogyakarta: Pustaka Pelajar, 2005), hlm. 212-213

${ }^{19}$ Haidar Putra Daulay, Pemberdayaan Pendidikan Islam di Indonesia, (Jakarta: Rineka Cipta, 2009), hlm. 8 
manusia tersebut dapat menjalankan hakikatnya sebagai makhluk yang diciptakan Allah dalam rangka menjadi abdullah (mempunyai kekokohan iman dan tingginya kualitas ketaqwaan kepada Allah yang dimanifestasikan dalam kualitas ibadah mahdlah dan ghairu mahdlah) sekaligus sebagai khalifatullah (untuk menjaga hubungan antar manusia agar tidak terjadi kesenjangan maupun pergesekan yang dapat mengarah pada tindakan kekerasan).

\section{Budaya Nirkekerasan sebagai Ruh Ajaran Islam}

Istilah nirkekerasan berasal dari kata dasar "keras," yang kemudian diimbuhi dan dikembangkan menjadi kata "kekerasan." Dalam Kamus Besar Bahasa Indonesia imbuhan "nir" berarti "tidak atau bukan." Sedangkan kata "kekerasan" punya tiga arti, yang pertama perihal atau sesuatu yang bersifat keras. Kedua, perbuatan seseorang atau sekelompok orang yang berakibat kecederaan atau kematian serta kerusakan fisik atau barang milik orang lain, ketiga, paksaan. ${ }^{20}$ Dengan demikian, dalam lingkup subjek, objek, tujuan, dan wilayahnya maka kekerasan bisa terjadi oleh siapa saja dan di mana saja.

Menurut Nimer, bahwa nirkekrasan adalah kombinasi antara sikap, pandangan, dan aksi yang dimaksudkan untuk mengajak orang di pihak lain secara damai supaya mengubah pendapat, pandangan, dan aksi mereka dengan capaian kedamaian pula. Oleh karena itu, dalam gerakan nirkekerasan para pelakunya tidak pernah membalas (merespon) tindakan the other dengan kekerasan. Sebaliknya, mereka meminimalkan kemarahan dan kerusakan secara holistik sambil menyampaikan pesan ketabahan yang tegas dan desakan untuk mengatasi ketidakadilan. ${ }^{21}$ Ini bukan berarti dalam sikap nirkekerasan seseorang hanya bersikap pasif tanpa perlawanan. Sebaliknya, perlawanan mereka dilakukan secara cerdas dan humanis yang berdasarkan pada prinsip nirkekerasan sehingga jauh lebih efektif dan tepat sasaran.

Dengan demikian gerakan nir-kekerasan ini bukan upaya secara individu melainkan upaya bersama dalam setiap masyarakat. Sehingga setiap orang memiliki paradigma bahwa gerakan nir-kekerasan merupakan cara yang paling efektif dalam menghadapi berbagai macam konflik yang ada di masyarakat dalam berbagai aspek kehidupan, termasuk dalam aspek kehidupan beragama.

20 Kamus Besar Bahasa Indonesia Luar Jaringan (Luring)," KBBI Offline Versi 1.5, http://kbbi-offline.googlecode.com/files/kbbi-offline-1.5.zip, didownload tanggal 20 November 2017

${ }^{21}$ Nimer, "Nirkekerasan dan Bina," Edisi Digital, didownload tanggal 20 November 2017, hlm. 20 
Budaya nirkekerasan merupakan budaya yang tumbuh dalam kondisi struktural dan kultural tertentu sebagaimana budaya kekerasan. Dengan mengetahui kondisi-kondisi struktural dan kultural yang memunculkan budaya kekerasan, secara tidak langsung akan diketahui pula kondisi yang melahirkan budaya nir-kekerasan. ${ }^{22}$

Chaiwat Satha Anand, mencoba untuk membuktikan bahwa nirkekerasan merupakan suatu hal yang jelas ada bahkan menjadi kewajiban seorang muslim untuk mewujudkannya. Beliau menjelaskan secara gamblang mengenai ajaran-ajaran agama besar di dunia yang pada intinya mengandung dan membawa pesan-pesan damai. Dimulai dari ajaran Islam, sebelum masuk kearah nilai dan pesan damai yang dibawanya, Islam sering kali dipandang sebagai agama yang mengajarkan kekerasan. Terutama pada konsep "jihad" yang menjadi banyak sorotan para pemikir Barat. Namun disini konsep Jihad yang sebenarnya bukanlah berperang ataupun melakukan tindakan kekerasan dengan membabi buta dan berlandaskan fanatisme. Justru Jihad yang sebenarnya adalah berarti menentang penindasan, kezaliman, dan ketidakadilan dalam semua bentuknya. ${ }^{23}$ Sebagaimana dalam kandungan Q.S. Al Maidah ayat 32.

Surat Al-Maidah ayat 32 ini menjadi titik tolak utama Chaiwat dan bahkan diambil sebagai judul pidato dan judul bukunya, untuk menunjukkan bahwa umat Islam memiliki kewajiban untuk melindungi nyawa manusia. Tetapi persoalannya, Islam juga memerintahkan umatnya untuk memerangi ketidakadilan, kadang sampai menghalalkan nyawa. Di sinilah Chaiwat menawarkan suatu solusi bernama aksi nirkekerasan. ${ }^{24}$

Telepas dari nilai ideal ajaran agama, yang mencerminkan tindakan nir-kekerasan dalam menyelesaikan konflik dan masalah, yang menjadi sebuah tantangan besar dalam mewujudkan tindakan nir-kekerasan adalah tindakan-tindakan ketidakadilan yang sangat sering terjadi dalam kehidupan social sehingga terjadilah pembangkangan social yang merupakan sebagai bentuk ekspresi dalam melawan ketidakadilan ini, dan tentunya dalam bentuk kekerasan. Negara sebagai sebuah institusi politik yang mewadahi kehidupan rakyatnya sudah seharusnya belajar untuk melakukan tindakan nir kekerasan, dan hal ini haruslah dimulai dari individu manusia masing-masing terlebih dahulu. ${ }^{25}$

${ }^{22}$ Yudith Chipordian, Memotong Lingkaran Kekerasan, https://yudhitc.wordpress.com /2008/10/24/memotong-lingkaran-kekerasan/ diakses 1 November 2017

23 Chaiwat Satha Anand, Barangsiapa Memelihara Kehidupan...": Esai-esai tentang Nirkekerasan dan Kewajiban Islam, pidato dalam rangka NMML [Nurkholis Madjid Memorial Lecture] di Universitas Paramadina, Jakarta, selasa 16 Oktober 2015 24 Ibid.

25 Minorityldeas, Konsep Nir-Kekerasan, http://blogcreativeminority. blogspot.co.id/2010/03/ konsep-nir-kekerasan.html, diakses 1 November 2017 
Budaya nirkekerasan tidak bisa diwujudkan jika solidaritas sebagai bangsa tak dapat ditumbuhkan. Solidaritas itu harus dibangun atas dasar ingatan bersama tentang perjuangan masa lalu dalam membangun bangsa dan kesediaan untuk berkorban demi masa depan bangsa. Solidaritas mencakup upaya-upaya mempertahankan dan mengembangkan rasa kebersamaan, saling menghormati, toleransi, empati, mau mengakui kesalahan serta siap mengorbankan kepentingan pribadi, kelompok dan golongan untuk kepentingan bangsa. ${ }^{26}$

Sehingga dengan membudayanya hal itu maka suatu masyarakat akan mampu menciptatakan budaya nirkekerasan dalam kehidupan manusia, dan hal ini merupakan suatu hal yang bisa diupayakan meskipun tantangan-tantangan yang besar akan selalu ada dihadapannya.

\section{Nilai-Nilai Ajaran Islam sebagai Budaya Nirkekerasan}

a) Islam adalah Rahmatan Lil'alamin

Menurut Ulwan, rahmat berarti kasih sayang yakni kelembutan hati dan kepekaa perasaan sayang terhadap orang lain, merasa sependeritaan, da ikut menghapus air mata kesedihan mereka. ${ }^{27}$ Agama Islam merupakan rahmat bagi seluruh alam, sebagaimana firman Allah dalam Q.S. Al-Anbiyaa'[21]: 107 "Dan Tiadalah Kami mengutus kamu, melainkan untuk (menjadi) rahmat bagi semesta alam." Dari ayat di atas dapat dipahami bahwasannya ajaran Islam bukan hanya merupakan rahmat bagi umat Islam sediri, melainkan juga rahmat (kasih sayang) bagi umat non-muslim, bahkan kasih sayang bagi makhluk lain. ${ }^{28}$

Jika dilihat dari hal ini tentunya Islam tidak pernah mengajarkan adanya tindakan kekerasan terhadap kaum minoritas atau kelompok minoritas yang seagama, maupun kepada orang lain yang tidak seagama. Dengan hal itu maka kerukunan antar umar seagama maupun antar umat beragama dapat dicapai.

b) Islam Membawa Pesan Perdamaian

Pesan perdamaian dalam Islam ini sebagaiamana dala firman Allah dalam QS. Al-Hujurat: 9-10. Dari ayat ini dapat dipahami bahwasannya Islam memerintahkan kepada umatnya selalu selalu berdamai dalam kondisi apapun, bahkan jika harus terjadi suatu perang karena alasan melanggar perjanjian perang maka setelah selesai permasalahannya juga harus tetap hidup damai.

26 Yudith Chipordian, Budaya Nirkekerasan, Niscayakah? https://yudhitc.wordpress.com/2008/10/24/budaya-nir-kekerasan-niscayakah/ 27 Abdullah Nasih Ulwan, Tarbiyah Al-Aulad Fi Al-Islam, terj. K.A Masykur Hakim, (Bandung: Remaja Rosdakarya, 1992), cet., ke-2, hlm. 11

28 Zainuddin Ali, Pendidikan Agama Islam, Jakarta: Bumi Aksara, 2007), hlm. 53 
Menurut Zainuddin Ali, ada beberapa hal yang dapat dilakukan oleh umat muslim dalam rangka menegakkan perdamaian diantaranya yaitu, dengan meneyebarluaskan salam, memberikan makanan kepada fakir miskin, menjalin silaturrahim dan hubungan yang baik dengan siapapun, dan melakukan shalat tahajjud di waktu orang lain tidur karena akan membawa kedamaian di hati. ${ }^{29}$

c) Islam Mengajarkan Toleransi

Toleransi dan nirkekerasan sebenarnya lahir dari sikap menghargai diri (self esteem) yang tinggi. Yakni bgaimana seseorang mempersepsikan dirinya adalah orang lain. Kalau kita tidak ingin disakiti, maka tidak menyakiti orang lain. Jika kita tidak suka kekerasan, maka orang lain pun juga tidak suka dikerasi. Jika persepsi masyarakat sudah demikian, maka muncul sikap toleransi dalam menghadapi keragaman. ${ }^{30}$

Hal ini senada dengan apa yang diungkapkan oleh Nurkholis Madjid, bahwasannya pada dasarnya toleransi adalah ajaran dan kewajiban melaksanakan ajaran itu. Jika toleransi itu menghasilkan kondisi yang baik di masyarakat maka, toleransi harus kita wujudkan dalam masyarakat. ${ }^{31}$ Menurut Cak Nur, toleransi merupakan sesuatu yang mendasar dalam ajaran Islam. Bahkan sejarah Islam sesungguhnya memiliki khazanah dan kekayaan pengalaman akan toleransi. ${ }^{32} \mathrm{Hal}$ ini sudah diakui oleh seorang ilmuwan Barat yakni Bertrand Russel, sebagaimana diungkapkan Cak Nur demikian:

"Agama Nabi (Islam) merupakan monotheisme yang tidak dibuat rumit oleh trinitas dan inkarnasi. Nabi tidak pernah mengklaim dirinya Tuhan. Sudah menjadi kewajiban orang beriman untuk menguasai dunia sebanyak mungkin demi Islam, tetapi sepanjang sejarah Beliau menyebarkan Islam tidak ada penganiayaan sedikitpun kepada Kristen, Yahudi maupun Zoroaster". ${ }^{33}$

d) Jihad dalam Islam

${ }^{29}$ Ibid., hlm. 62-63

30 Ngainun Naim, Islam dan Pluralisme Agama: dinamika Perebutan Makna, (Yogyakarta: Aura Pustaka, 2014), hlm. 182

31 Nurkholis Madjid, Cendekiawan dan Religiusitas Masyarakat, Kolom-kolom di Tabloid TEKAD, (Jakarta: TEKAD, 1999), hlm. 64

32 Nurkholis Madjid, Islam Agama Peradaban, Membangun Makna dan Relevansi Doktrin Islam dalam Sejarah, cet. ke-3, (Jakarta: Paramadina dan Dian Rakyat, 2008), hlm. 11

33 Nurkholis Madjid, Islam Agama Kemanusiaan: Membangun Tradisi dan Visi BAru Islam Indonesia, (Jakarta: Paramadina, 2003), hlm. 10 
Dalam memahami teks-teks al-Qur'an yang berkaitan dengan jihad ada beberapa orang yang memandang dari kacamata tekstualis saja, bukan kontekstualis, atau terkadang mereka memahami teks keagamaan bersifat lengkap dan final sehingga tidak memungkinkan adanya kebenaran (berada di kelompok atau agama) lain. ${ }^{34}$ Pemahaman mengenai konsep jihat sekaligus doktrin jihad dalam al-Qur'an yang cenderung tekstualis inilah yang terkadang dijadikan oleh beberapa kelompok-kelompok fundamentalis maupun kelompok muslim garis keras (radikal) sebagai landasan untuk melakukan kekerasan yang mengatasnamakan jihad fiisabiilillah.

Padahal sesungguhnya jihad dalam Islam tidak identik dengan kekerasan yang bernuansakan agama. Menurut Ali Musthofa Ya'kub, Islam adalah agama yang diturunkan untuk umat manusia, baik secara individu, kelompok, ataupun bangsa niscaya mereka akan menghadapi antara dua kondisi yaitu perang atau damai. ${ }^{35}$ Sebagaimana dalam kandungan QS. Al-Mumtahannah [60]: 8-9]

Dalam hal ini, Zakiyyudin Baidhawy, membuat perbedaan mendasar antara "mujahid terror" dan "mujahid damai" sebagai langkah pertama untuk mempertahankan argument bahwa aktor agama mewakili sumber potensial yang sangat kuat bagi perdamaian dan stabilitas politik. Kemudian ia juga memberikan gagasan bahwa para aktor agama mempunyai peran penting dalam mewujudkan perdamaian antara umat seagama maupun antar umat beragama. ${ }^{36}$

Memang secara tersurat maupun tersirat ada beberapa ayat alQur'an yang memberikan isyarat mengenai jihad di jalan Allah. Tetapi sesungguhnya jika diinterpretasi lebih dalam dan jika melihat dari konteks sejarah Islam terutama pada masa Nabi Muhammad, maka konsep jihad dalam Islam tidak hanya sekedar berperang mengangkat senjata, tetapi lebih urgen dari itu yaitu memerangi hawa nafsu yang tidak baik pada diri pribadi muslim itu sendiri.

\section{Pendekatan Interdisipliner dalam Budaya Nirkekerasan}

Pendekatan interdisipliner (interdisciplinary approach) ialah pendekatan dalam pemecahan suatu masalah dengan menggunakan tinjauan berbagai sudut pandang ilmu serumpun maupun ilmu yang

34 Haqiqul Yakin, Agama dan Kekerasan dalam Transmisi Demokrasi di Indonesia, (Yogyakarta: Sukses Offset, 2009), hlm. 29

35 Ali Musthofa Ya'kub, Meluruskan Makna Jihad dalam Islam, dalam buku "Peranan Pesantren dalam Mengembangkan Budaya Damai", ed. Nuhrison M. Nuh, (Jakarta: Maloho Jaya Abadi Press, 2010), hlm. 35

36 Zakiyuddin Baidhawy, Ambivalensi Agama dan Konflik dan Nirkekerasan, (Yogyakarta: Lesfi, 2002), hlm. 11 
relevan secara terpadu. Terpadu di sini maksudnya yaitu ilmu-ilmu yang digunakan dalam pemecahan suatu masalah melalui pendekatan ini terjalin satu sama lain secara tersirat (implicit) merupakan suatu kebulatan atau kesatuan pembahasan atau uraian termasuk dalam setiap sub-sub uraiannya. Ciri pokok atau kata kunci dari pendekatan indisipliner ini adalah inter (terpadu antar ilmu dalam rumpun ilmu yang sama). ${ }^{37}$

Jadi dalam konteks pendidikan agama Islam kajian mengenai nirkekerasan perspektif interdisipliner di sini adalah bagaimana PAI mengkaitkan dengan ilmu-ilmu lain yakni psikologi, sosiologi, biologi, dan sejarah dalam memandang nirkekerasan. Hal ini dikarenakan, kajian nirkekerasan berdasarkan kacamata PAI saja belum cukup untuk bisa menemukan konsep pendidikan agama Islam berbasis budaya nirkekerasan. Setidaknya ada 3 pendekatan yang digunakan.

a. Pendekatan Psikologi. Menurut pandangan psikologi behavioristik, yang dalam hal ini diungkapkan oleh J.B Watson (1941) bahwa proses mental dan juga perilaku yang teramati berperan dalam menyelaskan perilaku sosial. ${ }^{38}$ Dari pernyataan ini dapat dipahami bahwa motivasi seseorang dalam berperilaku sangat dipengaruhi oleh kondisi psikologis orang tersebut, termasuk dalam perilaku kekerasan. Sedangkan menurut pandangan psikologi kognitif yang dalam hal ini diungkapkan oleh Kurt Lewin bahwa perilaku ditentukan oleh totalitas situasi yang melingkupi seseorang. Dalam teori medan kognitifnya menjelaskan bahwa (totalitas faktafakta yang mengiringi dan dipahami saling tergantung atau terkait satu dengan yang lainnya). Setiap individu berperilaku berbeda sesuai dengan persepsi diri dan lingkungannya di mana ia tinggal maupun di mana ia bekerja. Oleh karena itu medan psikologis di mana orang berperilaku harus ditinjau, dalam rangka memahami perilaku seseorang tersebut. ${ }^{39}$

Selain itu, teori psikologi lain terkait dengan tindakan kekerasan adalah "kefrustasian." Menurut Buss sebagaimana dikutip Fromm, fursatasi adalah penghilangan hasrat atau keinginan dari individu yang ingin mencapai tujuan tertentu, sehingga terjadi

37 Setya Yuwana Sudikan, Pendekatan Interdisipliner, Multidisipliner, dan Transdisipliner dalam Studi Sastra, (Surabaya: UNESA), hlm. 4

38 James A. Wiggins, Beverly B. Wiggins, James Vander Zanden, Social Psychology, Fifth Edition, 1994, McGraw-Hill, Inc dalam (https://rizkian.wordpress.com/2011/06/22/budaya-kekerasan-di-indonesiadalam-perspektif-psikologi-sosial/), diakses 20 Desember 2017

${ }^{39}$ Kurt Lewin, Field Theory in Social Science; Selected Theoretical Papers. D. Cartwright (ed.). (New York: Harper \& Row), 1951, hlm. 240 
"putus harapan." 40 Jadi seseorang yang mengalami putus harapan atau frustasi bisa mendorong dirinya untuk melakukan tindakan kekerasan.

Sebagaimana diungkapkan oleh Naquib al-Attas bahwa tujuan akhir pendidikan Islam adalah menghasilkan manusia yang baik, yakni baik dalam kehidupan materiil dan kehidupan spirituilnya. ${ }^{41}$ Terkait dengan kontek budaya nirkekerasan perspektif psikologi ini, maka kehidupan spiritual seseorang inilah yang menjadi ladang bagi pendidikan Agama Islam untuk membinanya. Dengan penekanan aspek spiritual dalam pendidikan dan pembelajaran PAI, maka secara psikis peserta didik akan mampu membentuk jiwa yang cinta damai dan tidak menyukai perilaku kekerasan. Selain itu, PAI juga harus berupaya membentuk pribadi peserta didik yang mempunyai keimanan dan ketaqwaan yang kokoh, sehingga dengan bekal keimanan dan ketaqwaan yang kokoh ini peserta didik tidak mudah frustasi yang bisa menimbulkan aksi kekerasan.

b. Pendekatan Biologi. Otak manusia secara fisis-biologis sangat menentukan bagi perkembangan kecerdasan manusia tersebut. ${ }^{42}$ Keberadaan otak sebagai pusat pengolahan segala infomasi yang diterima oleh seseorang inilah tentunya sangat berpengaruh pada perilaku yang akan dilakukan oleh seseorang tersebut. Sehingga otak sebagai berfungsi sebagai pengendali dan pengontrol perilaku manusia sebagai bentuk dari respon terhadap stimulus-stimlus yang diterimanya.

Dalam pendekatan biologis menjelaskan bahwa setiap perilaku seseorang mendapatkan pengaruh biologis. Seperti halnya agresi atau kekerasan yang dilakukan seseorang itu karena dipengaruhi oleh faktor-faktor biologis. ${ }^{43}$ Otak dalam cabang ilmu biologi yang

40 Erich Fromm, "Akar Kekerasan: Analisis Sosio-psikologis atas Watak Manusia," dalam The Anatomy of Human Destructiveness, terj. Imam Muttaqin (Yogyakarta: Pustaka Pelajar, 2001), hlm. 83

${ }^{41}$ Mohammed Naquib al-Attas, The Concept of Education in Islam; A Framework for an Islamic Philosophy of Education, (Kuala Lumpur: ISTAC,1999), hlm. 22

42 Thomas Amstrong, "Seven Kinds of Smart: Menemukan dan Meningkatkan Kecerdasan Anda Berdasarkan Teori Multiple Intelligence," dalam Seven Kinds of Smart: Identifying and Developing Your Multiple Intelligences ed. T. Hermaya (Jakarta: Gramedia, 2005), hlm. 7

43 Asti Purwanti, Psikologi dalam Pendekatan Biologi, (https://astipurwanti07. wordpress.com/2014/01/15/psikologi-berdasarkan-pendekatan-biologi/), diakses 20 Desember 2017 
disebut dengan neurosains dikaji secara mendalam. Neurosains adalah ilmu yang khusus mempelajari neuron (sel saraf). ${ }^{44}$

Sedangkan neurosains pembelajaran adalah ilmu pengetahuan tentang hubungan sistem saraf dengan pembelajaran dan perilaku. ${ }^{45}$ Neurosains kognitif adalah ilmu yang menyediakan dan mempelajari dasar - dasar pikiran untuk lebih jauh lagi menyelidiki isu-isu lama terkait pikiran dan tubuh. ${ }^{46}$ Oleh karena itu, otak merupakan susunan syaraf pusat yang sangat berpengaruh pada perilaku seseorang termasuk perilaku kekerasan sebagai salah satu bentuk perilaku agresi. Otak bekerja dengan sistem pemikiran yang melintas. Artinya, otak tidak terdiri atas beberapa modul kecerdasan yang terpisah. Otak juga bukan sistem pemrosesan seri maupun sistem asosiatif yang terisolasi. Dua sistem ini berinteraksi dan saling menguatkan sehingga memberi manusia bentuk kecerdasan yang lebih tinggi daripada masing-masing kecerdasan tersebut jika berdiri sendiri. IQ dan EQ saling mendukung (sinergis). ${ }^{47}$

Oleh karena itu, pendidikan Agama Islam harus berupaya untuk membentuk pola pikir peserta didik agar peserta didik mempunyai pola pikir yang openminded dan multidimensional. Sehingga dengan pikiran yang terbuka ini, peserta didik tidak akan fanatis terhadap paradigmanya yang bersumber dari pikirannya sendiri yang akhirnya bisa mengarah pada perilaku ekstrim dan radikal atau kekerasan jika pemikiran orang lain berbeda atau bertentangan dengan pemikirannya.

c. Pendekatan Sosiologi. Yasraf Amir Piliang (dalam Adlin) menganggap bahwa modernisasi dapat menimbulkan banyak kesenjangan dan penderitaan sosial seperti penggusuran, pengusiran, perampasan hak milik dan pemerkosaan hak hidup. Fenomena ini disebut sebagai horror-culture yaitu kecenderungan dimana ketakutan dan horor dijadikan elemen utama pembentuk budaya. ${ }^{48}$ Dengan munculnya horror culture ini tentunya dapat menjadi salah satu faktor terjadinya tindakan-tidakan kekerasan di masryarakat.

44 Taufik Pasiak, Manajemen Kecerdasan Memberdayakan IQ, EQ dan SQ untuk Kesuksesan Hidup, (Bandung: PT. Mizan Pustaka, 2006), hlm. 46.

45 Dale H. Schunk, Learning Theories an Educational Perspektif, terj. Eva Hamidah dan Rahmat Fajar, Cet. I, (Bandung: Remaja Rosdakarya, 2012), hlm. 20.

46 Robertl L. Solso, dkk, Psikologi Kognitif,(Jakarta:Erlangga, 2007)

47 Danah Zohar dan Ian Marshall, "SQ: Kecerdasan Spiritual," (Bandung: Mizan Pustaka, 2007), hlm. 50

48 Alfatri Adlin, Spiritualitas dan Realita Kebudayaan Kontemporer, (Yogyakarta: Jalasutra, 2006), hlm. 201 
Hasan Hanafi memaparkan bahwa kekerasan muncul bila eksistensi manusia terancam. Ketidakadilan sosial merupakan salah satu bentuk keterancaman eksistensi tersebut, karena penghancuran bertentangan dengan eksistensi manusia. Dalam sejarah, institusi politik merupakan media ekspresi entitas manusia. Kekerasan sangat mungkin terjadi jika fungsi tersebut hancur dan kehidupan sosial tidak akan tertata. Fenomena ini disebut dengan diaspora. ${ }^{49}$

Menurut Gandhi sebagaimana dikutip oleh Salam mengasumsikan akar dari kekerasan terjadi ketika sebuah kehidupan tidak dilandasi hukum dan etika sosial.50 Selain itu, kondisi masyarakat yang plural dan multikultur juga dapat menyebabkan terjadinya pergesekan-pergesekan dan kesenjangan yang dapat mengarah pada timbulnya perilaku kekerasan. Perbedaan budaya, agama, etnik, suku, dan lain sebagainya menjadi salah satu faktor terjadinya perbedaan pendapat yang akhirnya bermuara pada tindakan kekerasan.

Dalam hal ini, pendidikan agama Islam juga dapat dijadikan sebagai wahana untuk mensosialisasikan nilai-nilai perdamaian di masyarakat. ${ }^{51}$ Dengan demikian pendidikan Agama Islam di sekolah mamapu berperan dalama mewujudkan manusia yang tidak hanya shaleh secara individu tetapi juga shalih secara sosial.

\section{Reorientasi dan Implementasi PAI Berwawasan Berbudaya Nirkekerasan}

Dalam hal ini, ada beberapa hal yang harus diemban oleh PAI tersebut, maka yang perlu dilakukan adalah reorientasi dan revitalisasi PAI dalam rangka membentuk budaya nirkekerasan baik di sekolah secara khusus maupun di masyarakat pada umumnya.

Pertama, Menurut Zainudin, harus ada reorientasi dalam Pendidikan Agama Islam. Orientasi Agama Islam tidak hanya menyangkut hal-hal luar seperti ritual, lambing-lambang dan sederet kesalihan ritual formalistik belaka, melainkan juga harus berorientasi untuk membentuk kesalehan sosial. ${ }^{2}$ Kedua, Pendidikan Agama Islam sejak di tingkat sekolah dasar pendidikan Agama Islam harus diarahkan tidak sekedar menjadikan

${ }^{49}$ Hasan Hanafi, Agama, Kekerasan, dan Islam Kontemporer, (Yogyakarta: Jendela, 2001), hlm. 17

${ }^{50}$ Burhanuddin Salam, Etika Sosial-Asas Moral Dalam Kehidupan Manusia, (Jakarta: Rineka Cipta, 1997), hlm. 129-136

${ }^{51}$ Muhaimin, Nuansa Baru Pendidkan Islam, (Jakarta: Raja Grafindo Persada, 2006), hlm. 141

52 Zainuddin, Kesalehan Normatif dan Sosial, (Malang: UIN-Malang Press, 2007), hlm. 132 
peserta didik sekedar tahu agama, tetapi mempunyai agama. Dengan demikian peserta didik akan mempunyai kesadaran untuk menjadikan ajaran agama sebagai landasan dalam berperilaku sehari-hari. Ketiga, pesan-pesan materi pendidikan Agama Islam setidaknya harus mencerminkan sifat toleran, inklusif, humanis, dan pluralis. ${ }^{53}$ Karena sesungguhnya dengan demikian, siswa tidak hanya akan tahu mengenai bagaimana cara beribadah kepada Allah tetapi juga tahu bagaimana seharusnya berinteraksi dengan orang lain.

Adapun dalam dalam tataran implementasi pendidikan Agama Islam berbudaya nirkekerasan di sekolah dapat diimplementasikan dalam bentuk integrasi dalam beberapa hal:

\section{a. Integrasi dalam Kegiatan Pembelajaran PAI}

Kegiatan intrakurikuler PAI yaitu kegiatan pembelajaran PAI yang dilaksanakan baik di dalam kelas maupun di luar kelas dengan mengacu pada pedoman kurikulum PAI di sekolah. Kegiatan ini merupakan upaya untuk menginternalisasikan nilai-nilai nirkekerasan kepada siswa. Dalam hal ini dapat diimplementasikan melalui beberapa kegiatan diantaranya:

1) Dalam proses pembelajaran di kelas, guru PAI harus senantiasa mengkaitkan materi yang diajarkan dengan perlunya menjaga budaya bina damai atau nirkekerasan, seperti mengenai bagaimana Islam mengajarkan toleransi (tasamuh) dan lain sebagainya. ;

2) Guru PAI mengajak siswa untuk melihat tampilan video pembelajaran yang terkait dengan ajaran al-Qur'an mengenai toleransi, serta video-vidoe sejarah kehidupan Nabi Muhammad dalam mengajarkan budaya perdamaian dan lain sebagainya kemudian mendiskusikan dengan kelompok. Karena dengan berdiskusi akan membiasakan siswa menghadapi perbedaan pendapat dan bagaimana menghadapi perbedaan pendapat itu;

3) Guru PAI mengajak siswa melakukan kunjungan atau studi banding kepada umat beragama lain, atau etnik lain dalam rangka mengajarkan toleransi dan saling menghargai;

4) Guru PAI memberikan tugas tidak tersturktur kepada siswa yang dalam tugas itu menghasilkan produk yang bermanfaat bagi sekolah untuk mewujudkan perdamaian atau budaya nirkekerasan. Contoh tugas tersebut misalnya siswa diminta untuk mengamati kehidupan orang yang berbeda agama kemudian dibuat dalam bentuk laporan tertulis.

\section{b. Integrasi dengan Kegiatan Ekstrakurikuler PAI}

${ }^{53}$ Ibid., hlm. 134 
Bentuk integrasi Pendidikan Agama Islam berbudaya nirkekerasan ke dalam kegiatan ekstrakurikuler ini dapat dilaksanakan dalam berbagai bentuk kegiatan diantaranya:

1) Guru PAI mengadakan kegiatan ekstrakurikuler Bahtsul Masail di sekolah, karena dengan kegiatan ini siswa dibiasakan untuk membahas permasalahan-permasalahan yang beranekaragama dan pendapat yang bervariasi;

2) Guru PAI mengadakan ekstrakurikuler seni Islami di sekolah, dengan adanya kegiatan seni Islami ini berfungsi untuk mengenalkan berbagai macam budaya yang ada yang terkait dengan ajaran Islam. Dengan demikian siswa akan lebih mengenal perbedaan dan itu bukan untuk dipermasalahkan yang bisa menimbulkan aksi kekerasan, melainkan justru menjadi sebuah karya seni yang indah yang bisa dinikmati, dan lain sebagainya.

\section{c. Pembentukan Budaya Sekolah berbasis Nirkekerasan}

Peraturan-peraturan, tata tertib, kebiasaan-kebiasa yang ada di sekolah merupakan wahana yang tepat untuk menanamkan nilai-nilai perdamaian dan budaya nirkekerasan dalam rangka mebentuk karakter peserta didik. Budaya-budaya sekolah yang ada harus mengandung nilai-nilai nirkekerasan.

Misalnya, pada saat awal masuk peserta didik mengikuti orientasi siswa. Dalam kegiatan orientasi siswa di awal tahun pelajaran ini hendaknya sudah mulai ditanamkan nilai-nilai budaya nirkekerasan. Selain itu, peraturan-peraturan dan tata tertib di sekolah harus jauh dari hal-hal yang mengarah pada perilaku kekerasan. Tata tertib di sekolah harus mengarah pada pembentukan sikap toleran, cinta damai, sopan-santun, kasih sayang, dan lain sebagainya.

Sekolah juga harus membentuk budaya salam, senyum, sapa di manapun, kapanpun, dan dengan siapapun. Karena dengan budaya ini, peserta didik akan lebih mengenal satu sama lain dan menjadikan siswa tidak tertutup dan arogan. Siswa akan menjadi orang yang lebih terbuka hatinya.

Itulah beberapa strategi yang dapat diterapkan dalam mengimplementasikan Pendidikan Agama Islam berbudaya nirkekerasan di sekolah. Selain itu, yang tidak kalah urgennya yaitu harus ada keteladanan dari semua guru kepada siswa dalam menunjukkan sikap bina damai atau nirkekerasan. Karena keteladanan dari kepala sekolah, semua guru dan karyawan yang ada 
di sekolah ini sangat efektif dalam membentuk budaya nirkekerasan di sekolah.

Selain itu, adanya kerjasama dengan berbagai pihak seperti guru mata pelajaran lain seperti guru PKN, guru seni dan lain sebagainya juga menjadi salah satu upaya dalam mewujudkan budaya nirkekerasan di sekolah. Dengan terintegrasinya nilai-nilai budaya nirkekerasan ke dalam setiap mata pelajaran tentunya akan lebih memudahkan pembentukan karakter peserta didik yang cinta damai dan toleran terhadap perbedaan, sehingga budaya nirkekerasan dapat diwujudkan. Untuk lebih memudahkan pemahaman mengenai impelementasi PAI berbudaya nirkekerasan dapat dilihat dalam gambar di bawah ini:

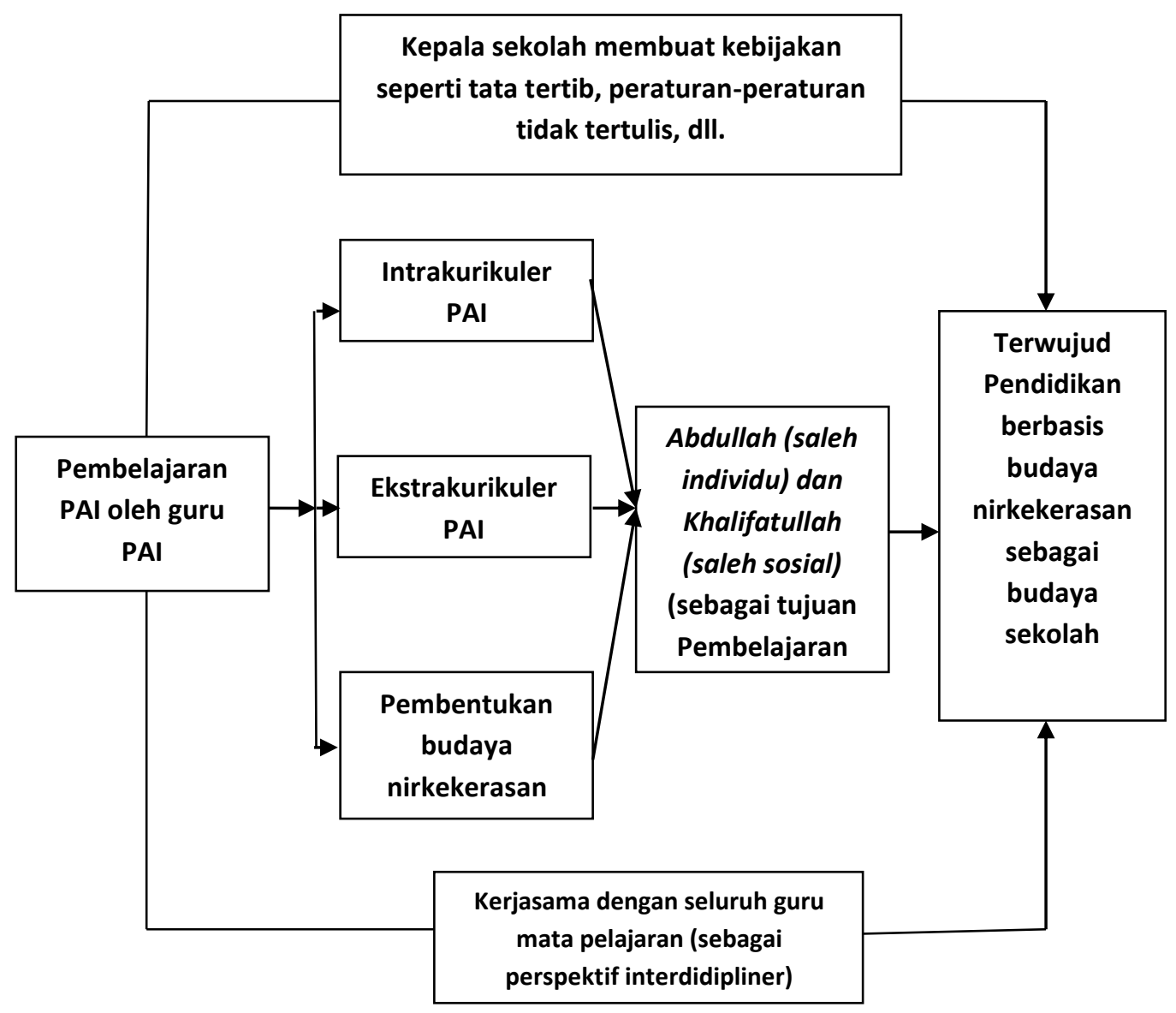

\section{Gambar 1.}

Implementasi Pendidikan Agama Islam

Berwawasan Budaya Nirkekerasan di Sekolah 


\section{Penutup}

Pendidikan Agama Islam adalah Pendidikan Agama Islam adalah proses ataupun usaha sadar untuk menumbuh kembangkan segala potensi manusia dengan memberi sifat keIslaman (berlandaskan al Qur'an dan hadits), sehingga terbentuk kepribadian muslim yang bertaqwa yakni mentaaati atau melaksanakan segala perintah Allah dan menjauhi segala yang dilarangNya, beramar ma'ruf nahi mungkar, serta memiliki nilai-nilai agama Islam, memilih, memutuskan, serta berbuat berdasarkan nilai-nilai Islam dan bertanggung jawab sesuai dengan nilai-nilai Islam. PAI berlandaskan al-Qur'an dan hadits sebagai sumber utamanya, dan menggunaka ra'yu sebagai sumber pendukung. Adapun tujuan dari PAI adalah menyiapkan manusia untuk menjalankan perannya sebagai Abdullah yang shaleh dalam individu dan khalifatullah yang shaleh dalam social.

Budaya nirkekerasan adalah kombinasi antara sikap, pandangan, dan aksi yang dimaksudkan untuk mengajak orang di pihak lain secara damai supaya mengubah pendapat, pandangan, dan aksi mereka dengan capaian kedamaian pula. Dalam Islam, budaya nirkekerasan merupakan ruh ajaran Islam itu sendiri. Islam adalah rahmatan lil'alamin, Islam membawa pesan perdamaian dan kerukunan, Islam mengajarkan toleransi, dan Islam memberikan konsep jihad bukan berarti kekerasan atau paksaan kepada orang lain untuk menjadi Islam, melainkan jihad adalah bagaimana menaklukkan kekufuran yang menjelma sebagai perilaku imoral.

PAI berbasis budaya nirkekerasan adalah PAI yang mampu menciptakan budaya kasih sayang, perdamaian, kerukunan, dan toleransi dalam kehidupan sehari-hari, baik di sekolah, di rumah, maupun di masyarakat. Kemudian budaya-budaya itu lebih dalam lagi diinternalisasikan menjadi suatu karakter dari peserta didik yang shaleh secara individu dan social. Oleh karena itu PAI harus berorientasi tidak hanya pada masalah ritual saja melainkan juga interaksi social, PAI harus bisa menjadikan manusia tidak sekedar tahu agama tetapi mempunyai agama, dan pesan-pesan materi pendidikan Agama Islam setidaknya harus mencerminkan sifat toleran, inklusif, humanis, dan pluralis. Adapun dalam tataran implementasi PAI berbasis budaya nirkekerasan di sekolah dapat dilakukan dalam bentuk integrasi dengan kegiatan intrakurikuler PAI, integrasi dengan kegiatan ekstrakurikuler PAI, dan integrasi dengan ekologi atau budaya sekolah. Selain itu adanya kebijakan dari pimpinan dan keteladanan dari guru maaupun integrasi dengan semua mata pelajaran juga sangat diperlukan dalam mewujudkan budaya nirkekerasan di sekolah. 
JURNAL PIWULANG, Vol. I No. 1 September 2018, 68-89

\section{DAFTAR RUJUKAN}

Adlin, Alfatri. 2006. Spiritualitas dan Realita Kebudayaan Kontemporer. Yogyakarta: Jalasutra

Al-Attas, Mohammed Naquib. 1999. The Concept of Education in Islam; A Framework for an Islamic Philosophy of Education. Kuala Lumpur: ISTAC

Ali, Mohammad Daud. 2006. Pendidikan Agama Islam. Jakarta: Raja Grafindo Persada

Ali, Zainuddin. 2007. Pendidikan Agama Islam, Jakarta: Bumi Aksara

Amstrong, Thomas . 2005. "Seven Kinds of Smart: Menemukan dan Meningkatkan Kecerdasan Anda Berdasarkan Teori Multiple Intelligence," dalam Seven Kinds of Smart: Identifying and Developing Your Multiple Intelligences ed. T. Hermaya. Jakarta: Gramedia

Anand, Chaiwat Satha. 2015. Barangsiapa Memelihara Kehidupan...": Esai-esai tentang Nirkekerasan dan Kewajiban Islam, pidato dalam rangka NMML [Nurkholis Madjid Memorial Lecture] di Universitas Paramadina, Jakarta, selasa 16 Oktober 2015

Baharuddin. 2005. Aktualisasi Psikologi Islami, Yogyakarta: Pustaka Pelajar

Baidhawy, Zakiyuddin. 2002. Ambivalensi Agama dan Konflik dan Nirkekerasan, Yogyakarta: Lesfi

Chipordian, Yudith. Budaya Nirkekerasan, Niscayakah? https://yudhitc.wordpress.com/2008/10/24/budaya-nir-kekerasanniscayakah/

Chipordian, Yudith. Memotong Lingkaran Kekerasan, https://yudhitc.wordpress.com/2008/10/24/memotong-lingkarankekerasan/, diakses 1 November 2017

CNN Indonesia, Puluhan Jenazah Warga RohingnyaDitemukan di Bangladesh, Kamis, 31/08/2017

Daud, Wan Mohd Nor Wan .1998. The Educational Philosophy and Practice of Syed Muhammad Naquib Al-Attas: AnExposition of the Original Concept of Islamization. Kuala Lumpur: ISTAC1

Daulay, Haidar Putra. 2009. Pemberdayaan Pendidikan Islam di Indonesia. Jakarta: Rineka Cipta

Fromm, Erich . 2001. "Akar Kekerasan: Analisis Sosio-psikologis atas Watak Manusia," dalam The Anatomy of Human Destructiveness, terj. Imam Muttaqin. Yogyakarta: Pustaka Pelajar

Hanafi, Hasan. 2001. Agama, Kekerasan, dan Islam Kontemporer. Yogyakarta: Jendela

International Crisis Group,"Indonesia: From Vigintalism to Terrorism in Cirebon," Asia Briefing No. 132, 12 January 2012

Jalaluddin. 2003. Teologi Pendidikan. Jakarta: PT Raja Grafindo Persada 
Jalaluddin. 2004. Psikologi Agama. Jakarta: PT. RajaGrafindo Persada

Jones, Sidney. 2013 Sisi Gelap Reformasi Indonesia: Munculnya Kelompok Masyarakat Madani Intoleran, (disampaikan sebagai NMML [Nurcholish Madjid Memorial Lecture ke VII], 2013), Jakarta: PUSAD

Kamus Besar Bahasa Indonesia (KBBI) online, https://kbbi.web.id/interdisipliner, diakses 20 Desember 2017

Kholiq, Abdul, dkk. 1999. Pemikiran Pendidikan Islam, kajian Tokoh Klasik dan Kontemporer. Yogyakarta: Pustaka Pelajar

Lewin, Kurt. 1951. Field Theory in Social Science; Selected Theoretical Papers. D. Cartwright (ed.). (New York: Harper \& Row

Madjid, Nurkholis. 1999. Cendekiawan dan Religiusitas Masyarakat, Kolomkolom di Tabloid TEKAD. Jakarta: TEKAD

Madjid, Nurkholis. 2003. Islam Agama Kemanusiaan: Membangun Tradisi dan Visi Baru Islam Indonesia. Jakarta: Paramadina

Madjid, Nurkholis. 2008. Islam Agama Peradaban, Membangun Makna dan Relevansi Doktrin Islam dalam Sejarah, cet. ke-3. Jakarta: Paramadina dan Dian Rakyat

MinorityIdeas,

Konsep

Nir-Kekerasan,

http://blogcreativeminority.blogspot.co.id/2010/03/konsep-nir-

kekerasan.html, diakses 1 November 2017

Mubarak, Husni Tragedi Rohingnya dan Diskursus Kekerasan Agama, Jurnal Kelas CRCS, 4 September 2017 (Yogyakarta: Pusat Studi Agama dan Lintas Budaya Sekolah Pascasarjana UGM), http://crcs.ugm.ac.id/id/berita-utama/11384/tragedi-rohingya-dandiskursus-kekerasan-agama.html, diakses 1 November 2017

Muhaimin. 2006. Nuansa Baru Pendidkan Islam. Jakarta: Raja Grafindo Persada Mukhtar. 2003. Desain Pembelajaran PAI. Jakarta: Misaka Galiza

Muzani, Saiful. Pandangan Dunia dan Gagasan Islamisasi Ilmu Syed Muhammad Naquib Al-Attas, dalam Jurnal Hikmah, No. 3 Juli-Oktober 1991

Naim, Ngainun. 2014. Islam dan Pluralisme Agama: dinamika Perebutan Makna, Yogyakarta: Aura Pustaka

Nata, Abuddin. 1997. Filsafat Pendidikan Islam, Jakarta: Logos Wacana Ilmu

Nimer, Mohammed Abu "Nirkekerasan dan Bina-Damai dalam Islam: Teori dan Praktek," dalam Nonviolence and Peace Building in Islam: Theory and Practice, terj. M. Irsyad Rhafsadi dan Khairil Azhar. EDISI DIGITAL, http://www.abad-demokrasi.com/sites/default/files/

ebook/Nirkekerasan\%20Abu-Nimer.pdf, didownload tanggal 20 November 2017

Pasiak, Taufik. 2006. Manajemen Kecerdasan Memberdayakan IQ, EQ dan SQ untuk Kesuksesan Hidup. Bandung: PT. Mizan Pustaka. 
JURNAL PIWULANG, Vol. I No. 1 September 2018, 68-89

Purwanti, Asti. Psikologi dalam Pendekatan Biologi, (https://astipurwanti07.wordpress.com/2014/01/15/psikologiberdasarkan-pendekatan-biologi/), diakses 20 Desember 2017

Pusat Studi Agama dan Demokrasi Yayasan Paramadina (PUSAD), http://www.paramadina-pusad.or.id/pustaka/barangsiapamemelihara-kehidupan-esai-esai-tentang-nirkekerasan-dankewajiban-islam, diakses 1 November 2017

Salam, Burhanuddin. 1997. Etika Sosial: Asas Moral dalam Kehidupan Manusia. Jakarta: Rineka Cipta

Schunk, Dale H. 2012. Learning Theories an Educational Perspektif, terj. Eva Hamidah dan Rahmat Fajar, Cet. I. Bandung: Remaja Rosdakarya20.

Solso, Robertl L. 2007. dkk, Psikologi Kognitif. Jakarta: Erlangga

Sudikan, Setya Yuwana.-. Pendekatan Interdisipliner, Multidisipliner, dan Transdisipliner dalam Studi Sastra. Surabaya: UNESA

Ulwan, Abdullah Nasih. 1992. Tarbiyah Al-Aulad Fi Al-Islam, terj. K.A Masykur Hakim, Bandung: Remaja Rosdakarya

Wiggins, James A. dkk. 1994. Social Psychology, Fifth Edition. McGraw-Hill, Inc dalam https://rizkian.wordpress.com/2011/06/22/budayakekerasan-di-indonesia-dalam-perspektif-psikologi-sosial/), diakses 20 Desember 2017

Ya'kub, Ali Musthofa. 2010. Meluruskan Makna Jihad dalam Islam, dalam buku "Peranan Pesantren dalam Mengembangkan Budaya Damai", ed. Nuhrison M. Nuh. Jakarta: Maloho Jaya Abadi Press

Yafie, Ali. 1997. Teologi Sosial, Yogyakarta: LKPSM

Yakin, Haqqul. 2009. Agama dan Kekerasan dalam Transmisi Demokrasi di Indonesia, Yogyakarta: Sukses Offset

Zainuddin, 2007. Kesalehan Normatif dan Sosial. Malang: UIN-Malang Press

Zohar, Danah dan Ian Marshall. 2007. "SQ: Kecerdasan Spiritual,". Bandung: Mizan Pustaka

Zuhdiyah. 2009. Pendidikan Agama Islam. Palembang: Universitas PGRI 